\title{
Improved Treatment Technique for the Reuse of Waste Solution Generated from a Electrokinetic Decontamination System
}

\section{동전기제염장치에서 발생한 폐액의 재사용을 위한 개선된 처리기술}

\author{
Wan-Suk Kim*, Seung-soo Kim, Gye-Nam Kim, Uk-Ryang Park, and Jei-Kwon Moon \\ Korea Atomic Energy Research Institute, 111 Daedeokdaero 989, Yuseong-gu, Daejeon, Korea \\ 김완석*, 김승수, 김계남, 박욱량, 문제권 \\ 한국원자력연구원, 대전광역시 유성구 대덕대로 989 번길 111
}

(Received January 8, 2014 / Revised January 29, 2014 / Approved February 4, 2014)

\begin{abstract}
A large amount of acidic waste solution is generated from the practical electrokinetic decontamination equipments for the remediation of soil contaminated with uranium. After filtration of uranium hydroxides formed by adding $\mathrm{CaO}$ into the waste solution, the filtrate was recycled in order to reduce the volume of waste solution. However, when the filtrate was used in an electrokinetic equipment, the low permeability of the filtrate from anode cell to cathode cell due to a high concentration of calcium made several problems such as the weakening of a fabric tamis, the corrosion of electric wire and the adhension of metallic oxides to the surface of cathode electrode. To solve these problems, sulfuric acid was added into the filtrate and calcium in the solution was removed as $\mathrm{CaSO}_{4}$ precipitate. A decontamination test using a small electrokinetic equipment for 20 days indicated that Ca-removed waste solution decreased uranium concentration of the waste soil to $0.35 \mathrm{~Bq} / \mathrm{g}$, which is a similar to a decontamination result obtained by distilled water.
\end{abstract}

Keywords: Electrokinetic Remediation, Waste solution, Decontamination, Uranium, Reuse, $\mathrm{CaSO}_{4}$

우라늄으로 오염된 토양을 복원하기 위해 실규모의 동전기제염장치로 제염하는 과정에서 많은 산폐액이 발생한다. 발생한 산폐액에 $\mathrm{CaO}$ 를 가해 우라늄수산화물을 침전시켜 여과한 다음, 방사성 폐액을 줄이기 위하여 이 용액을 재사용하였다. 그 러나 이 용액을 동전기에 재사용할 경우, 높은 농도의 칼슘 때문에 양극실에서 음극실로 용액이동 속도가 감소하여 여과포 의 약화, 전선 부식, 음극면에 산화물 부착 등의 문제점이 발생하였다. 이 문제들을 해결하기 위하여 재생액에 황산을 넣어 $\mathrm{CaSO}_{4}$ 로 침전시켜 칼슘을 제거하였다. 칼슘이 제거된 재생액을 사용하여 소형 동전기 장치에서 20 일간 토양제염 실험을 수 행한 결과는 세척후 토양내 우라늄 잔류 농도가 $0.35 \mathrm{~Bq} / \mathrm{g}$ 로 감소하였으며, 이는 증류수 제염한 결과와 유사하게 나타났다.

중심단어: 동전기 복원, 폐수, 제염, 우라늄, 재사용, $\mathrm{CaSO}_{4}$

*Corresponding Author.

Wan-Suk Kim, Korea Atomic Energy Research Institute, E-mail: zickim@kaeri.re.kr, Tel: +82-42-868-8524 
Wan-Suk Kim et al. : Improved Treatment Technique for the Reuse of Waste Solution Generated from a Electrokinetic Decontamination System

\section{1.서 론}

방사성 물질로 오염된 토양을 복원하기 위하여 토양세 척이 효과적인 정화방법으로 제시되었으나[1], 이 토양세척 방법은 미량의 잔류 방사능까지 제염하는 데는 한계가 있 다. 따라서 최근에는 오염토양 복원 기술로서 동전기 기술 (Electrokinetic Technology) 에 대한 연구가 진행되었고, 현 재 한국원자력연구원 내에 실규모의 동전기 처리장치가 운 영되고 있다. 그러나 우라늄으로 오염된 토양을 동전기 장치 로 처리하려면 우라늄을 포함하는 많은 양의 산 폐액이 발생 한다[2]. 이 방사성 폐액은 처리되거나 재사용되여야 하는데, 폐액을 증발건조시킬 경우 너무 많은 에너지가 소모되므로 대부분 적절한 처리를 통하여 재사용을 한다.

본 실험실에서는 우라늄을 포함하고 있는 동전기 폐액으 로부터 우라늄을 침전시키기 위하여 중성 혹은 약염기 조건 에서, 황산알루미늄과 마그네타이트를 폐액에 첨가하였다[3, 4]. 황산알루미늄의 적정사용 $\mathrm{pH}$ 는 $9 \sim 10$ 으로 알려져 있 다. 우라늄 제염을 위해서는 동전기에서 사용하는 세척액의 $\mathrm{pH}$ 가 1이하로 유지되어야 하기 때문에, 세척 후 우라늄이 침 전되는 $\mathrm{pH}$ 영역으로 만들기 위해 많은 양의 염기성 약품을 넣 게 된다[5]. 이때 넣는 약품으로는 흔히 $\mathrm{CaO}, \mathrm{NaOH}$ 를 사용 되는데, $\mathrm{NaOH}$ 는 $\mathrm{pH}$ 를 빠르게 높이는 반면, 폐액처리 후 나 오는 재생액에 소디움이 용해되어 있어 재사용시 소디움 농 도가 계속 농축되어 결국 고체상태로 석출된다. 이 소디움이 온은 수용액에서 용해도가 매우 커서 이를 선택적으로 제거 하기가 쉽지 않다.

$\mathrm{CaO}$ 를 사용한 폐액처리는 $\mathrm{NaOH}$ 보다 용해속도가 느려 $\mathrm{pH}$ 를 9이상으로 올리는데 시간이 많이 소요되나, $\mathrm{NaOH}$ 보 다 적은 양으로 $\mathrm{pH}$ 를 높일 수 있다. $\mathrm{CaO}$ 로 처리한 폐액의 재생액에도 칼슘이온이 잔류하게 되지만 보편적으로 소디 움 화합물보다는 칼슘 화합물이 침전되기 쉬우므로 제거가 쉽다. 따라서 본 연구에서는 동전기 폐액의 중화를 위하여 $\mathrm{CaO}$ 를 사용하였고, 이 폐액으로부터 칼슘을 제거하여 이 재 생액을 동전기 장치에 재사용하는 방법을 연구하였다.

\section{2. 실험 재료 및 방법}

\section{1 실험재료}

실험에 사용된 재생액은 한국원자력연구원 내의 토양제 염설비인 동전기의 폐액처리 장치에서 처리가 된 재생액을 사용하였다. 동전기 폐액은 $\mathrm{pH}$ 0.5 1.0이며, 우라늄 외에 $\mathrm{Al}, \mathrm{Fe}, \mathrm{Zn}, \mathrm{Pb}$ 등이 폐액에 녹아있다. 폐액처리장치에서는 폐액을 중화시키기 위해 $\mathrm{CaO}$ 를 사용하여 $\mathrm{pH}$ 를 9까지 높힌 다. 이때 우라늄을 제거하기 위해 응집제(황산알루미늄)와 흡착제(마그네타이트)를 넣어 침전시킨 후 필터프레스로 고 형물과 용액을 분리한다. 분리된 용액을 재사용하여 폐액발 생을 억제시킨다. 방사능 오염토양 세척액 중 우라늄을 침전 시키고 필터프레스를 통과한 폐액처리장치에서 얻은 용액을 본 실험에 사용하였다.

용액 중 칼슘을 선택적으로 침전시키기 위하여 흔히 사 용하는 무기 음이온은 carbonate와 sulfate이다. 즉, $\mathrm{CaCO}_{3}$ 와 $\mathrm{CaSO}_{4}$ 는 수용액에서 낮은 용해도를 갖는다. 이들 칼슘 화합물을 형성하기 위하여 수용액에서 금속이온 농도를 증 가시키지 않고 사용할 수 있는 시약은 $\mathrm{H}_{2} \mathrm{CO}_{3}$ 와 $\mathrm{H}_{2} \mathrm{SO}_{4}$ 인데, $\mathrm{H}_{2} \mathrm{CO}_{3}$ 은 이산화탄소를 고압에서 수용액에 용해시켜 놓은 것이나 일반적으로 탄산수는 이산화탄소 기체가 탄산이온 으로 용해되어 있기보다는 용액 중에 기체상태로 존재하기 때문에 본 실험에서는 황산 $\left(\mathrm{H}_{2} \mathrm{SO}_{4}\right.$, DUKSAN, Korea, 95\%) 을 사용하였다.

\section{2 실험방법}

우라늄을 침전시키고 필터프레스를 통과한 용액 $1 \mathrm{~L}$ 를 각각의 비이커로 옮겨서 황산 원액을 조금씩 넣고 천천히 저 어주어 $\mathrm{CaSO}_{4}$ 침전물이 생기도록 유도하였다, 침전에 사용 할 황산의 적정 양을 알기 위해 황산의 주입 양을 각각 10,50 , $100,150 \mathrm{~mL}$ 재생액에 첨가하였다. 반응 후 침전된 $\mathrm{CaSO}_{4}$ 를 분리하기 위해 원심분리기를 사용하여 여액과 고형물을 분 리한 다음, 고형물을 $105^{\circ} \mathrm{C}$ 에서 2 시간 동안 건조하였다. 황 산 첨가 전후의 칼슘 농도 변화와 고형물의 무게를 측정하여 칼슘 제거량을 측정하였다.

또한, 칼슘이 제거된 재생액을 소형 동전기에 사용하여 실증 실험을 하였다. 우라늄의 농도가 $6.5 \mathrm{~Bq} / \mathrm{g}$ 정도로 오염 된 토양을 동전기로 20 일 동안 가동을 하며, 칼슘이 제거된 재생액을 사용하였다. 동일한 방법으로 칼슘을 제거한 재생 액과 제거하지 않은 용액, 그리고 증류수를 사용하여 이들 결 과를 상호 비교하여 칼슘제거 효과를 고찰하였다. 


\section{3 분석방법}

용액 중 칼슘농도는 ICP-AES(Inductively Coupled Plas ma-Atomic Emission Spectroscopy, JY Ultima-2C, Jobin Yvon, 프랑스)로 분석하였다. 우라늄 농도는 한국표준과학 연구원에서 제작한 $50 \mathrm{~mL}$ 의 QCY48 표준용기에 시료를 담 아 HPGe Gamma-Ray Spectroscopy System(GC2018, Canberra, 미국)의 분석기인 MCA (Multi-Channel Analyzer)를 사용하여 계측하였다. 방사능 농도 분석을 위하여 시료당 4 8 시간 동안 측정하였다.

\section{3. 결과 및 고찰}

\section{1 재생액의 특성}

방사능 오염 토양의 동전기 제염처리 과정에서 배출되는 우라늄 및 산화물의 폐액으로부터 우라늄을 침전·응집시키 기 위한 공정은 중성 이상의 $\mathrm{pH}$ 에서 진행되어야 하므로 $\mathrm{pH}$ 상승을 위해 $\mathrm{CaO}$ 를 사용하여 공정이 수행되었다(Fig. 1). 이 로 인해 폐액 처리 후 재생액에는 칼슘이온 농도가 매우 높 아 이 재생액을 다시 동전기에 사용할 경우, 동전기 내의 토 양층을 잘 통과하지 못하며, 음극표면에 부착하여 전극에서 의 전류의 흐름을 방해시켜 제염 효율을 낮춘다. 또한, 이 재 생액 중 우라늄 침전시킨 후 계속적으로 재생해서 사용할 경 우, $\mathrm{pH}$ 를 높일 때 사용하는 $\mathrm{CaO}$ 가 용액 내 칼슘의 포화도 때 문에 폐액 내에 잘 녹지 않고 $\mathrm{pH}$ 의 변화에 민감하게 반응하 지 않아 더 많은 양을 넣어, 결국에는 슬러지의 양까지 증가 시키는 결과를 낳았다. 본 연구에서는 여러 번의 폐액처리 가 된 재생액을 채취하여 시험하였다. Table 1은 재생액에 녹아있는 주 원소들을 ICP-AES를 이용하여 분석한 결과를 나타내었다. 그 결과 주 원소는 $\mathrm{Ca}, \mathrm{Fe}, \mathrm{Ni}$ 이며, 칼슘의 농도 가 $3.8 \%$ 로 재생액에 상당한 양이 녹아있는 것으로 나타났다.

\section{2 재생액 침전처리}

고 농도의 칼슘이 녹아있는 폐액 재생액을 칼슘을 처리 하지 않고 동전기에 바로 공급하면 여러 가지 문제가 발생하 는데, 그 중 다음 3 가지의 문제점이 크게 나타났다.
Table 1. The concentration of ions in the solutions before and after addition of sulfuric acid

\begin{tabular}{ccc}
\hline & $\begin{array}{c}\text { Before addition } \\
\mathrm{mg} / \mathrm{L}\end{array}$ & $\begin{array}{c}\text { After addition } \\
\mathrm{mg} / \mathrm{L}\end{array}$ \\
\hline $\mathrm{Ca}$ & 37,900 & 752 \\
\hline $\mathrm{Fe}$ & $<5$ & 2.4 \\
\hline $\mathrm{Ni}$ & $<5$ & 2.2 \\
\hline
\end{tabular}
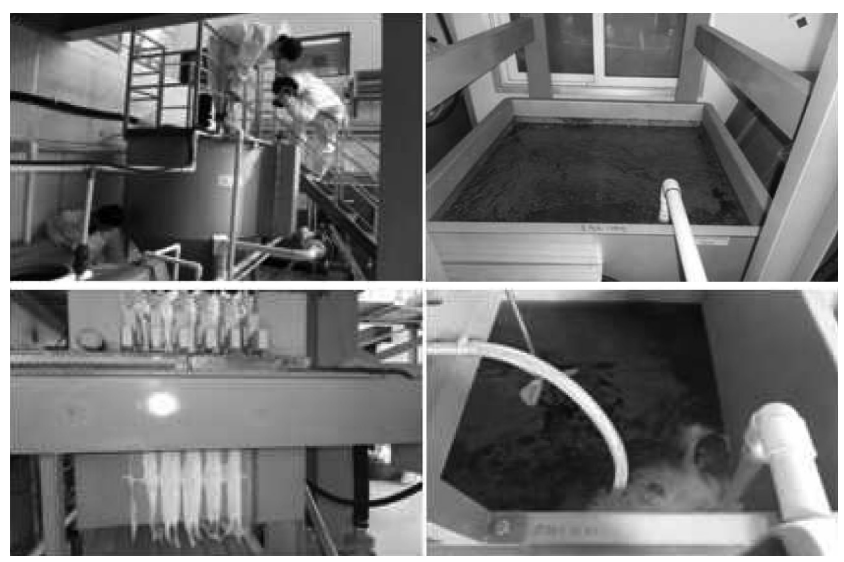

Fig. 1. Treatment equipments of uranium-containing wastewater; A) Neutralizing equipment, B) Separator , C) Filter press, D) Reclaimed water storage tank.

1) 용액이 양극에서 음극으로 잘 흐르지 못해 양극 용액 이 전극 판의 전선연결 부분까지 상승하여 연결부위를 부식시키기 때문에 저항이 증가하여 전선이 끊어지고, 화재발생의 위험이 있다.

2) 용액의 투과가 늦어짐에 따라 물 가수분해에 의해 양 극 부분에서 발생하는 수소이온에 의해 용액이 강 산 성으로 유지되는 시간이 증가하므로 여과포가 쉽게 파손되어 토양이 유실될 뿐만 아니라 여과포를 재사 용할 수 없게 된다.

3) 용액의 투과속도가 늦어지면 음극의 폐액이 배출구로 빠져나가는 속도가 늦어지므로 용액 중 금속산화물과 칼슘이온의 농도가 높아져 음극판에 달라붙게 된다. 이는 전류의 흐름을 방해하여 제염효율을 떨어뜨리므 로 결국에는 제염시간이 길어진다(Fig. 2).

따라서 재생액을 재사용하기 위해서는 재생액 내의 칼슘을 
Wan-Suk Kim et al. : Improved Treatment Technique for the Reuse of Waste Solution Generated from a Electrokinetic Decontamination System
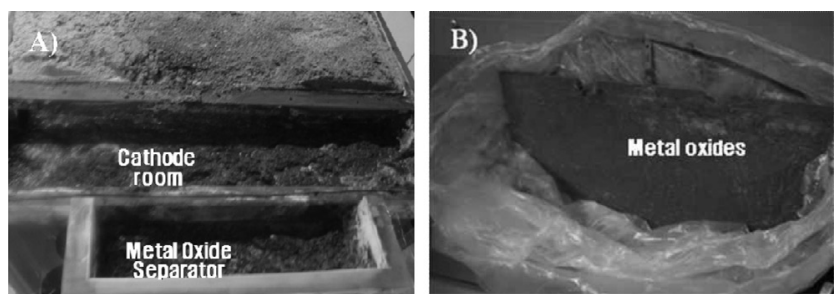

Fig. 2. A) Metal oxide of cathode room, B) Cathode plate covered by metal oxide.

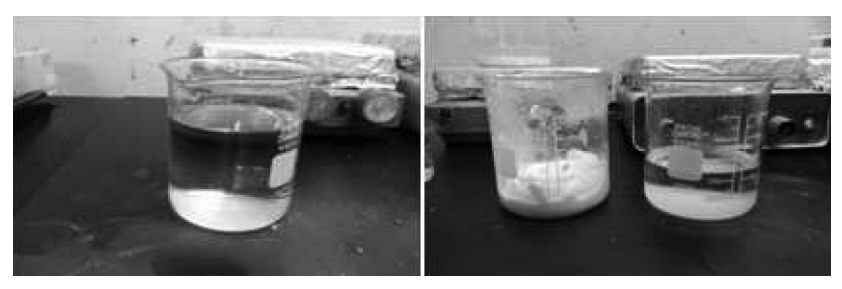

Fig. 3. Precipitation by adding sulfuric acid into reclaimed water.

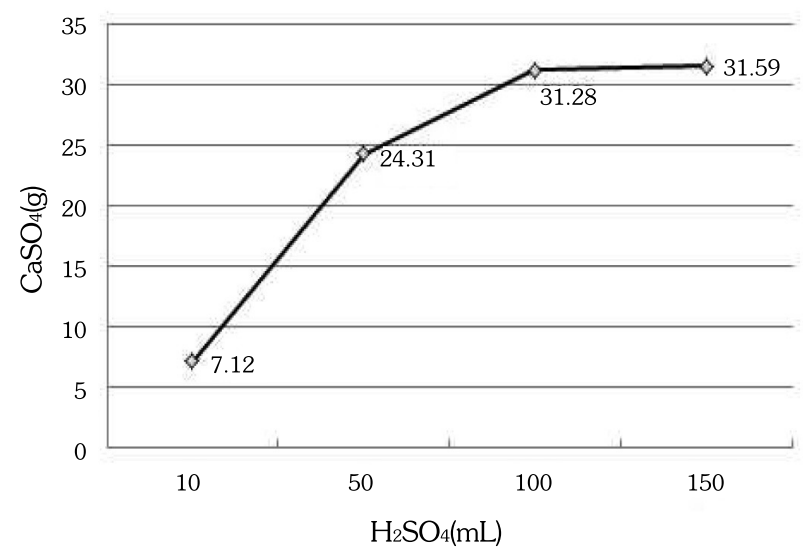

Fig. 4. The amount of $\mathrm{CaSO}_{4}$ precipitation as a function of added volume of sulfuric acid.

제거하여야 한다. 칼슘을 제거하기 위하여 황산을 사용하였 는데, 폐액처리 시 폐액의 $\mathrm{pH}$ 가 항상 일정한 범위에 있지 않 기 때문에 $\mathrm{pH}$ 를 높일 때 쓰이는 $\mathrm{CaO}$ 의 첨가 양이 항상 같지 않다. 그러므로 재생액을 ICP-AES로 분석하여 칼슘의 농도 를 추정하여 황산을 넣는 것이 보다 경제적일 것이다. Fig. 3 은 재생액에 황산을 첨가하였을 때 침전되는 $\mathrm{CaSO}_{4}$ 를 나타
냈으며, Fig. 4 에는 황산의 첨가량에 따른 $\mathrm{CaSO}_{4}$ 의 무게변화 를 나타낸 그래프이다. $\mathrm{CaSO}_{4}$ 의 생성은 황산 $100 \mathrm{~mL}$ 이상을 넣었을 때 더 이상 침전의 무게가 변하지 않았으므로 대부분 의 칼슘이 침전된 것으로 판단된다. 황산으로 처리한 최종 용액 중 칼슘의 농도가 $752 \mathrm{mg} / \mathrm{L}$ 으로 초기 재생액의 칼슘이 온 농도와 비교하였을 때, 제거 효율이 약 $98 \%$ 로 높게 나타 났다(Table 1).

\section{3 개선한 재생액 성능 및 제염효율}

칼슘을 황산으로 처리한 재생액 즉, 개선된 재생액이 동 전기 사용 시 문제점으로 발생되었던 현상들이 개선되었는 지 알아보기 위해 파이롯트 규모 동전기 실험을 수행하였다. 우라늄의 초기 농도가 $6.5 \mathrm{~Bq} / \mathrm{g}$ 정도로 오염된 토양을 동전 기로 20 일 동안 개선된 재생액을 사용하여 가동을 하였다 (Fig. 5). 개선된 재생액을 사용한 결과 개선 전의 재생액을 사용했을 때 발생되었던 투수 방해 현상이 눈에 띄게 감소되 어 물의 이동이 원활하였다. 여과포의 부식 정도 또한 개선 전의 재생액을 사용했을 때 발생되었던 현상들이 발생되지 않았고, 전선의 부식도 일어나지 않아 화재의 위험에서 벗어 났다. 또한, 금속산화물의 배출이 용이해져 음극판에 들러붙 는 금속산화물의 양도 눈에 띄게 줄어들었다.

개선된 재생액의 제염효율을 알아보기 위해 3 대의 동전 기에서 각각 우라늄 농도가 $6 \sim 6.5 \mathrm{~Bq} / \mathrm{g}$ 정도로 오염된 토양 을 넣고, 20 일 동안 증류수, 재생액, 개선된 재생액으로 운 영하였다. 그 결과 개선된 재생액과 물의 오염농도는 개선 된 재생액 $0.35 \mathrm{~Bq} / \mathrm{g}$, 물 $0.32 \mathrm{~Bq} / \mathrm{g}$ 으로 $95.1 \%$ 이상의 효율 이 나타났다(Fig. 6). 그러나 재생액을 사용한 동전기는 다른 동전기들보다 느리게 제염이 되었고, 오염농도는 $1.42 \mathrm{~Bq} / \mathrm{g}$ 으로 다른 용액보다 상대적으로 높은 농도이며, 제염효율도 $77.1 \%$ 로 낮은 수준이다. 이러한 결과로 칼슘이 제거된 재생 액은 동전기 장치성능에 문제없이 제염효율을 높이고 폐액 량을 획기적으로 줄일 수 있음을 확인하였다.

\section{4. 결론}

방사능 오염 폐액을 처리한 칼슘이 많이 포함된 재생액 을 재사용할 경우 동전기 양극실과 음극실의 물흐름이 늦어 


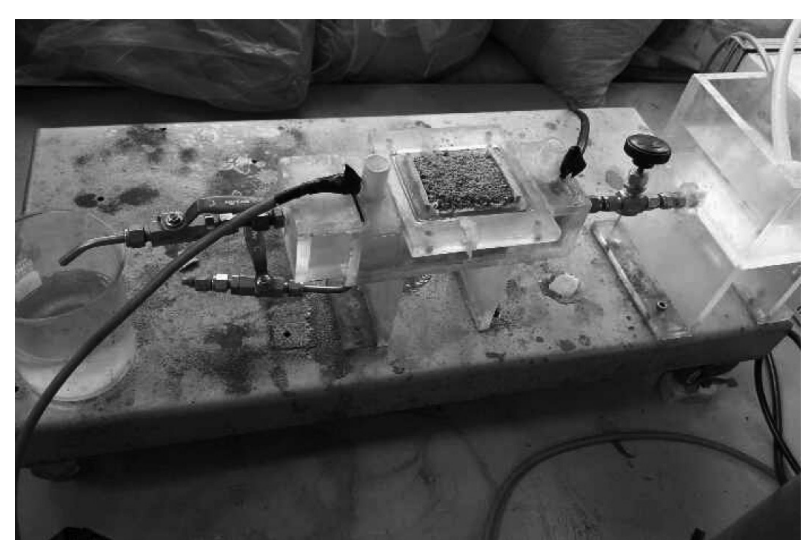

Fig. 5. A decontamination test of small electrokinetic equipment using Ca-removed water.

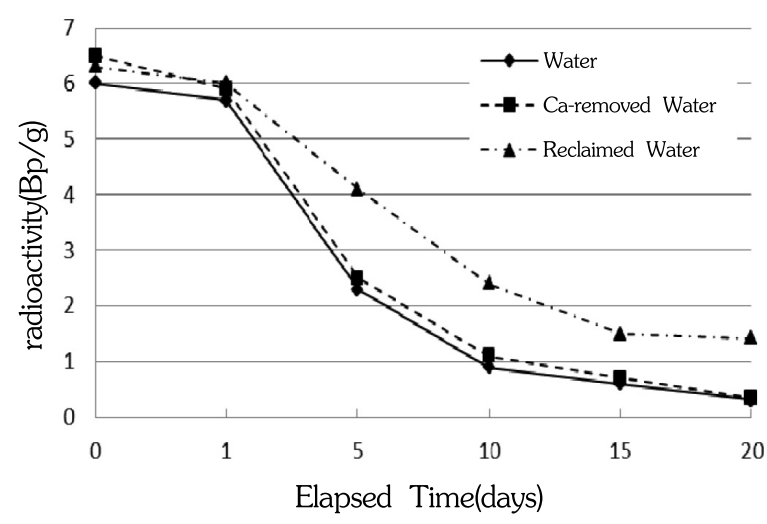

Fig. 6. The radioactivity of uranium as a function of elapsed time in various solutions.

져 여과포 부식, 전극 부식, 음극표면에 많은 양의 금속산화 물이 부착되어 전류 흐름을 방해하는 문제점이 발생하였다. 그러나 이 재생액에 황산을 넣어 $\mathrm{CaSO}_{4}$ 침전을 형성하여 칼 슘농도를 제거한 경우, 이들 문제점이 해결되었으며 제염효 율도 물을 사용한 경우와 유사하게 20 일 만에 우라늄을 자 체처분규제농도인 총 우라늄 농도 $1.0 \mathrm{~Bq} / \mathrm{g}$ 이하로 제염되 었다.

실규모 폐액처리장치에 적용 시 칼슘침전을 형성시키는 장치와 필터프레스로 칼슘침전물을 제거하는 장치를 추가 배치하면 개선된 재생액이 동전기에 물 대신 사용이 가능하
여 폐액발생량을 상당히 줄일 수 있을 것이다.

\section{감사의 글}

This work was supported by Nuclear Research \& Development Program of the Korea Science and Engineering Foundation (KOSEF) grant funded by the Korean government (MEST).

\section{REFERENCES}

[1] G.N. Kim, W.K. Choi, C.H. Bung, and J.K. Moon, "Development of a washing system for soil contaminated with radionuclides around Triga reactor", J. Ind. Eng. Chem., 13, pp. 406-413 (2007).

[2] G.N. Kim, D.B. Shon, H.M. Park, K.W. Lee, and U.S. Chung, "Development of pilot-scale electrokinetic remediation technology for uranium removal", Separation and purification technology, 80, pp. 6772 (2011).

[3] G.Blanchard, M.Maunaye, and G.Martin, "Removal of heavy metals from waters by means of natural zeolites", Water Research, 18(12), pp. 1501-1507 (1984).

[4] Debasish Das, M.K. Sureshkumar, Siddhartha Koley, Nidhi Mithal, and C.G.S. Pillai. "Sorption of uranium on magnetite nanoparticles", J. Radioanal Nucl Chem, 285(3), pp. 447-454 (2010).

[5] H.M. Park, G.N. Kim, S.S. Kim, W.S. Kim, U.R. Park, and J.K. Moon, "Improvement of pilot-scale electrokinetic remediation technology for uranium removal", J. Korean Radiact. Waste Soc., 11(2), pp. 77-84 (2013).

[6] W.S. Wan Ngah and M.A.K.M. Hansnfiah, "Removal of heavy metal ions from wastewater by chemically modified plant wastes as adsorbents: A review", Bioresource Technology, 99, pp. 3935- 
Wan-Suk Kim et al. : Improved Treatment Technique for the Reuse of Waste Solution Generated from a Electrokinetic

3948 (2008).

[7] Raymond Le Van Mao, Ngoc Thanh Vu, Shuyong Xiao, and Arlene Ramsarn, "Modified Zeolites for the Removal of Calcium and Magnesium from Hard Water", J. MATER. CHEM, 4(7), pp. 1143-1147 (1994).

[8] Lucy Mar Camacho, Shuguang Deng, and Ramona R. Parra, "Uranium removal from groundwater by natural clinoptilolite zeolite: Effects of $\mathrm{pH}$ and initial feed concentration", Journal of hazardous Materials, 175, pp. 393-398 (2010).

[9] K. Reddy, C.Y. Xu, and S. Chinthamreddy, "Assessment of electrokinetic removal of heavy metals form soil by sequentical extraction analysis", J. Hazard. Mater., B84, pp. 279-296 (2001).

[10] K. Reddy and S. Chinthamreddy, "Sequentially enhanced electrokinetic remediation of heavy metals in low buffering clayey soils", J. Geotech. Geoenviron. Eng., March, pp. 263-277 (2003).

[11] F. Braud, S. Tellier, and M. Astruc, "Modelling of decontamination rate in an electrokinetic soil processing", Int. J. Environ. Anal. Chem., 68, pp. 105-121 (1998).

[12] S.O. Kim, S.H. Moon, and K.W. Kim, "Removal of heavy metals from soils using enhanced electrokinetic soil precessing", Water, Air, Soil Pollution, 125, pp. 259-272 (2001).

[13] S. Scapolan, E. Ansoborlo, C. Moulin, and C. Madic, "Uranium speciation in biological medium by means of capillary electrophoresis and timeresolved laser induced fluorescence", J. Radioanal. Nucl. Chem., 226, pp. 145-148 (1997).

[14] G.E. Collins and Q. Lu, "Microfabricated capillary electrophoresis sensor for uranium (VI)", Anal. Chim. Acta., 436, pp. 181-189 (2001).

[15] A.P. Shapiro and R.F. Probstein, "Removal of contaminants from saturated clay by electro osmosis", Environ. Sci. Technol. 27, pp. 283-291 (1993).

[16] R. Lageman, W. Pool, and G. Seffinga, "Electro- reclamatiom: theory andpractice", Chem. Ind., 8, pp. 585-590 (1989).

[17] M.M. Page and C.L. Page, "Electroremediation of contaminated soils", J. Environ. Eng., ASCE 128, pp. 208-219 (2002).

[18] M. Macka, P. Nesterenko, and P.R. Haddad, "Investigation of solute-wall interaction in separation of uranium(VI) and lanthanides by capillary electrophoresis using on-capillary complexation with arsenazo III", J. Microcolumn Sep., 11, pp. 1-9 (1999). 